\title{
Poly (N-vinylpyrrolidone) Modification Mitigates Plasma Protein Corona Formation on Phosphomolybdate-based Nanoparticles
}

\section{Youyi Yu}

Shanghai Jiao Tong University

\section{Behafarid Ghalandari}

Shanghai Jiaotong University School of Biomedical engineering

\section{Guangxia Shen}

Shang hai Jiaotong Unviersity School of Biomedical engineering

\section{Liping Wang}

Shanghai Jiaotong University School of biomedical engineering

\section{Xiao Liu}

Shanghai Jiaotong University School of biomedical engineering

\section{Aiting Wang}

Shanghai Jiao Tong University School of biomedical engineering

\section{Sijie Li}

Shanghai Jiao Tong University School of Biomedical engineering

\section{Haiyang Xie}

Shanghai Jiao Tong Unviersity School of biomedical engineering

Xianting Ding ( $\nabla$ dingxianting@sjtu.edu.cn )

Shanghai Jiao Tong University School of Biomedical Egnieering

\section{Research Article}

Keywords: Phosphomolybdate, zwitterionic polymer poly (N-vinylpyrrolidone), plasma protein corona, mass spectrometry

Posted Date: September 7th, 2021

DOI: https://doi.org/10.21203/rs.3.rs-864653/v1

License: (1) (1) This work is licensed under a Creative Commons Attribution 4.0 International License. Read Full License 
Version of Record: A version of this preprint was published at Journal of Nanobiotechnology on December 1st, 2021. See the published version at https://doi.org/10.1186/s12951-021-01140-8. 
1 Poly (N-vinylpyrrolidone) Modification Mitigates Plasma Protein Corona

2 Formation on Phosphomolybdate-based Nanoparticles

3 Youyi Yu, Behafarid Ghalandari, Guangxia Shen, Liping Wang, Xiao Liu, Aiting Wang,

$4 \quad$ Sijie Li, Haiyang Xie* and Xianting Ding*

5 State Key Laboratory of Oncogenes and Related Genes, Institute for Personalized Medicine,

6 School of Biomedical Engineering, Shanghai Jiao Tong University, Shanghai, 200030,

7 China.

8 ABSTRACT

9 Phosphomolybdate-based nanoparticles (PMo 12 -based NPs) have been commonly applied in nanomedicine. However, upon contact with biofluids, proteins are quickly adsorbed onto the NPs surface to form a protein corona, which induces the opsonization and facilitates the rapid clearance of the NPs by macrophage uptake. Herein, we introduce a family of structurally homologous PMo12-based NPs (CDS-PMo12@ $\mathrm{PVP}_{\mathrm{x}}(\mathrm{x}=0 \sim 1)$ NPs) capping diverse content of zwitterionic polymer poly (N-vinylpyrrolidone) (PVP) to regulate the protein corona introduction of PVP effectively reduces the number of binding sites of proteins on CDS-PMo ${ }_{12} @ \mathrm{PVP}_{0}$ NPs. The liquid chromatography-tandem mass spectrometry (LC-MS/MS) is further applied to analyze and quantify the compositions of the human plasma corona formation on CDS-PMo ${ }_{12} @ \mathrm{PVP}_{\mathrm{x}}(\mathrm{x}=0 \sim 1)$ NPs. The number of plasma protein 
groups adsorption on CDS-PMo ${ }_{12} @ \mathrm{PVP}_{1} \mathrm{NPs}$, compared to CDS-PMo ${ }_{12} @ \mathrm{PVP}_{0} \mathrm{NPs}$, decreases from 372 to 271 . In addition, 76 differentially adsorption proteins are identified between CDS-PMo ${ }_{12} @ \mathrm{PVP}_{0}$ and CDS-PMo ${ }_{12} @ \mathrm{PVP}_{1} \mathrm{NPs}$, in which apolipoprotein is up-regulated in CDS-PMo ${ }_{12} @ \mathrm{PVP}_{1}$ NPs. The apolipoprotein adsorption onto the NPs is proposed to have dysoponic activity and enhance the circulation time of NPs. Our findings demonstrate that PVP grafting on PMo12-based NPs is a promising strategy to improve the anti-biofouling property for $\mathrm{PMo}_{12}$-based nanodrug design.

KEY WORDs: Phosphomolybdate, zwitterionic polymer poly (N-vinylpyrrolidone), plasma protein corona, mass spectrometry

\section{INTRODUCTION}

Phosphomolybdate $\left(\mathrm{PMo}_{12}\right)$-based nanocomposites and hybrids[1-7] have been reported with potentials for the treatment of vast types of cancers.[8-13] The nanoparticles (NPs) tend to undergo nonspecific protein adsorption (formation of "protein corona") when entering the physiological system[14-16] The "protein corona" complexes consist of dozens of proteins including apolipoproteins, adhesion mediators, signaling and transport proteins, and coagulation factors.[17] These native or conformational proteins act as opsonins that enable a nanomaterial for efficient uptake by the mononuclear phagocytes system (MPS).[18-20] To reduce NPs clearance by the MPS, shielding groups on NPs surfaces are required to block opsonins proteins binding to NPs.[18] These groups tend to be long hydrophilic polymer chains and nonionic surfactants. Some polymers include polyethylene glycol (PEG), polysaccharides, polyacrylamide, and PEG-containing copolymers as examples of shielding 
groups. PEGylated Doxil nanodrug has been used as clinical medicine, yet PEG cannot completely shield protein adsorption[21] to modulate the immune response.

The poly(N-vinyl-2-pyrrolidone) (PVP) zwitterionic polymer is a sub-class of polyampholytes that possess equivalent positive and negative charges on the same pendant group maintaining overall electrical neutrality.[22] A correlation between surface charge and opsonization has been demonstrated in vitro, with research showing that neutrally charged NPs have a much lower opsonization rate than charged NPs.[23] In addition, studies on PMo12-based NPs mainly focus on the design and screening of potent PMo12-based nanomaterials,[24,25] as well as their pharmacology study.[14,26] Limited effort has been devoted to the protein corona formation mechanism on zwitterionic polymer modified PMo12-based NPs. Herein, we synthesized a series of structurally homologous PMo12-based NPs (CDS-PMo $\left.12 @ \mathrm{PVP}_{\mathrm{x}}(\mathrm{x}=0 \sim 1) \mathrm{NPs}\right)$ capping diverse content of zwitterionic polymer poly (N-vinylpyrrolidone) (PVP) by micelle-based approach. The cesium dodecyl sulfate $\left(\mathrm{C}_{12} \mathrm{H}_{25} \mathrm{SO}_{4} \mathrm{Cs}\right.$, CDS $)$ cationic surfactant is used to trap the $\mathrm{PMo}_{12} \mathrm{O}_{40}{ }^{3-}$ polyanion for preparing CDS-PMo $12 @ \mathrm{PVP}_{0}$ NPs (Scheme 1a).[25] When the PVP is introduced to the reaction system, PVP firstly interacts with CDS to form CDS-PVP complex through the electrostatic/hydrophobic forces.[27] The CDS-PVP complex matrix decelerates the contact rate of the CDS and the $\mathrm{PMo}_{12} \mathrm{O}_{40}{ }^{3-}$ polyanion. Besides, the PVP polymer adhered to the surface of CDS-PMo12@ $\mathrm{PVP}_{\mathrm{x}}(\mathrm{x}=0.05 \sim 1) \mathrm{NPs}$ serves as a protective layer to prevent the further aggregation of NPs. Consequently, the PVP that added to the reaction system 
manages to regulate the size and the surface properties of CDS-PMo ${ }_{12} @ \mathrm{PVP}_{\mathrm{x}}(\mathrm{x}=0.05 \sim 1)$ NPs.

As a proof of concept, $\mathrm{Cyt}-\mathrm{C}, \mathrm{Hb}$, and BSA were adopted as representative basic, neutral, and acidic proteins to investigate protein adhesion behaviors on CDS-PMo $\mathrm{PM}_{12} @ \mathrm{PVP}_{\mathrm{x}}(\mathrm{x}=0 \sim 1)$ NPs. The adsorption efficiencies were gradually decreased when the PVP content increased, suggesting the addition of PVP suppresses the adsorption of protein to NPs (Scheme 1b-c). Fluorescence quenching measurements further unveiled the underlying interaction mechanism between proteins and two typical PMo ${ }_{12}$-based NPs $\left(\mathrm{CDS}-\mathrm{PMo}_{12} @ \mathrm{PVP}_{\mathrm{x}}(\mathrm{x}=0,1)\right.$ NPs). The introduction of PVP influences the binding kinetics and thermodynamic process of protein adsorption, reducing the number of binding sites, and subsequently influences the adsorption of protein. The hydrophobic interactions are identified as the driving forces for proteins binding to CDS-PMo ${ }_{12} @ \mathrm{PVP}_{0} \mathrm{NPs}$, while the electrostatic interactions are identified as the main forces between proteins and CDS-PMo $\mathrm{Po}_{12} @ \mathrm{PVP}_{1}$ NPs. The specific binding sites and contact surface area (CSA) were further visualized by molecular docking computational simulations. The CSA of proteins binding on CDS-PMo ${ }_{12} @ \mathrm{PVP}_{0} \mathrm{NPs}$ is larger than that of CDS-PMo ${ }_{12} @ \mathrm{PVP}_{1}$ NPs. Importantly, the CSA of Cyt-C is larger than that of Hb and BSA on CDS-PMo ${ }_{12} @ \mathrm{PVP}_{\mathrm{x}}(\mathrm{x}=0,1)$. Next, a series of CDS-PMo ${ }_{12} @ \mathrm{PVP}_{\mathrm{x}}(\mathrm{x}=0 \sim 1)$ NPs were incubated with human plasma, the composition of the plasma protein corona was examined by label-free liquid chromatography mass spectrometry (LC-MS/MS). Along with the increase of PVP content, the number of identified protein groups covering the CDS-PMo ${ }_{12} @ \mathrm{PVP}_{\mathrm{x}}(\mathrm{x}=0 \sim 1)$ NPs decreases gradually. Moreover, 76 differential adsorption 
proteins between CDS-PMo $\mathrm{PM}_{12} @ \mathrm{PVP}_{0}$ and CDS-PMo $\mathrm{PM}_{12} @ \mathrm{PVP}_{1} \mathrm{NPs}$ are identified, in which apolipoprotein is up-regulated of the plasma corona proteins on CDS-PMo ${ }_{12} @ \mathrm{PVP}_{1} \mathrm{NPs}$. Researches have proved that the adsorption of apolipoproteins can prolong circulation times.[28] Therefore, our studies demonstrate that PVP grafting on $\mathrm{PMo}_{12}$-based NPs mitigates plasma protein corona formation, which provides a new potential strategy for PMo12-based nanodrug design with better biological sustainability.
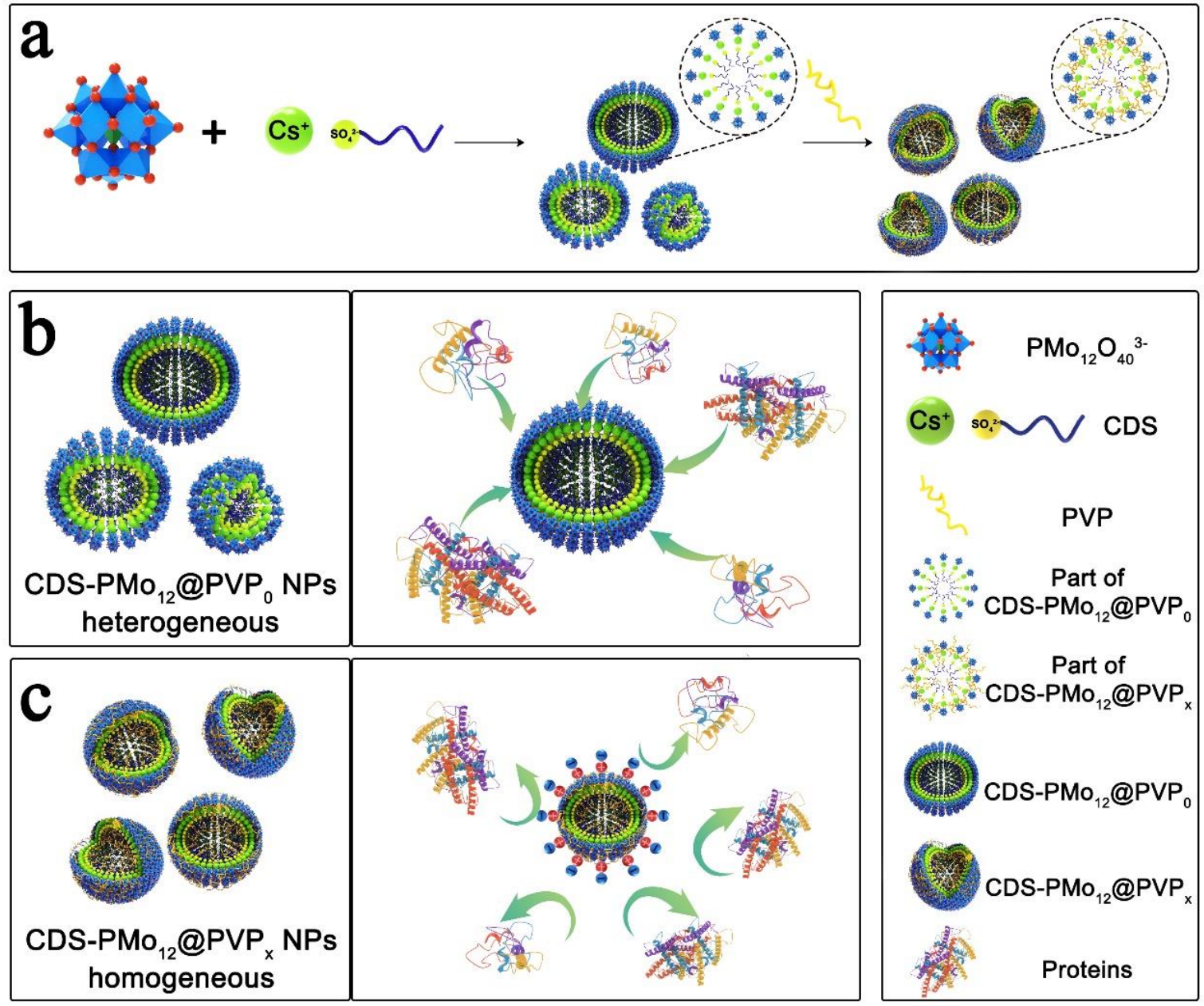

Scheme 1 Preparation of CDS-PMo ${ }_{12} @ \mathrm{PVP}_{\mathrm{x}}(\mathrm{x}=0 \sim 1)$ NPs for decreased adsorption of serum proteins. (a) CDS is used as a cationic nucleating agent to trap the $\mathrm{PMo}_{12} \mathrm{O}_{40}{ }^{3-}$ polyanion to synthesize CDS-PMo ${ }_{12} @ \mathrm{PVP}_{0}$ NPs. The introduction of PVP to the CDS-PMo ${ }_{12} \mathrm{O}_{40}{ }^{3-}$ reaction system further synthesizes homogenous CDS-PMo ${ }_{12} @ \mathrm{PVP}_{\mathrm{x}}(\mathrm{x}=0.05 \sim 1)$ NPs. (b) 
Heterogeneous CDS-PMo ${ }_{12} @ \mathrm{PVP}_{0}$ NPs without PVP coating protection could largely adsorb proteins. (c) In contrast, PVP modified homogeneous CDS-PMo ${ }_{12} @ \mathrm{PVP}_{\mathrm{x}}(\mathrm{x}=0.05 \sim 1) \mathrm{NPs}$ could protect the NPs from protein adsorption.

\section{RESULTS AND DISCUSSIONS}

\section{Synthesis and Characterization of CDS-PMo12@PVP $(x=0 \sim 1)$ NPs.}

The CDS-PMo $\mathrm{PO}_{12} @ \mathrm{PVP}_{\mathrm{x}}(\mathrm{x}=0 \sim 1) \mathrm{NPs}$ were prepared by a micelle-based approach (Figure 1a) with detailed experiment process given in the Supporting Information (SI). Figure $1 \mathrm{~b}$ and Figure S1 provide the transmission electron microscopy (TEM) images of CDS-PMo ${ }_{12} @ \mathrm{PVP}_{\mathrm{x}}(\mathrm{x}=0 \sim 1)$ NPs. CDS-PMo $\mathrm{Po}_{12} @ \mathrm{PVP}_{0} \mathrm{NPs}$ are heterogeneous, with sizes ranging from 100 to $1000 \mathrm{~nm}$. The $\mathrm{CDS}-\mathrm{PMo}_{12} @ \mathrm{PVP}_{\mathrm{x}}(\mathrm{x}=0 \sim 1) \mathrm{NPs}$ size distributions are statistically analyzed from TEM images by ImageJ software (Figure S2). The main size of $\mathrm{CDS}^{\mathrm{PMMo}}{ }_{12} @ \mathrm{PVP}_{\mathrm{x}}(\mathrm{x}=0.05 \sim 1) \mathrm{NPs}$ are approximately 520, 482, 454, 300, $235 \mathrm{~nm}$, respectively. The size of particles became smaller (from $520 \mathrm{~nm}$ to $235 \mathrm{~nm}$ ) and more homogeneous with the increase of PVP content. The size of CDS-PMo ${ }_{12} @ \mathrm{PVP}_{\mathrm{x}}(\mathrm{x}=0 \sim 1) \mathrm{NPs}$ was further verified by dynamic light scattering (DLS) analysis (Figure 1c). Besides, the morphology of CDS-PMo $\mathrm{PPVP}_{12}$ NPs were characterized by the high-angle annular darkfield scanning transmission electron microscopy (HAADF-STEM, Figure 1d), and the corresponding elemental compositions were analyzed by energy-dispersive X-ray spectroscopy (EDS) in HAADF-STEM. According to the HAADF-STEM-EDS elemental mapping, we found that the $\mathrm{O}, \mathrm{Mo}, \mathrm{P}, \mathrm{Cs}, \mathrm{C}$, and $\mathrm{N}$ elements exist simultaneously, illustrating the PVP successfully anchored to the CDS-PMo12@PVP ${ }_{1}$ NPs.[25] Figure 1e showed the 
116 X-ray diffraction (XRD) patterns of CDS-PMo ${ }_{12} @ \mathrm{PVP}_{\mathrm{x}}(\mathrm{x}=0 \sim 1)$ NPs. The $2 \theta$ diffraction

117 peaks correspond to the crystalline phase peaks of the $\mathrm{H}_{3}\left[\mathrm{PMo}_{12} \mathrm{O}_{40}\right]$,[29] indicating that the 118 prepared $\mathrm{PMo}_{12}$-based NPs retain the $\mathrm{H}_{3}\left[\mathrm{PMo}_{12} \mathrm{O}_{40}\right]$ Keggin structure. The FT-IR spectra of 119 CDS-PMo ${ }_{12} @ \mathrm{PVP}_{0}, \mathrm{CDS}-\mathrm{PMo}_{12} @ \mathrm{PVP}_{0.5}$, and CDS-PMo12@PVP $\mathrm{P}_{1}$ showed the presence of absorption bands of the $\mathrm{PMo}_{12} \mathrm{O}_{40}{ }^{3-}\left(\mathrm{P}-\mathrm{O}_{\mathrm{a}}\right.$ at $1064 \mathrm{~cm}^{-1}, \mathrm{Mo-} \mathrm{O}_{\mathrm{d}}$ at $962 \mathrm{~cm}^{-1}, \mathrm{Mo}-\mathrm{O}_{\mathrm{b}}$ at 869 $\mathrm{cm}^{-1}$, and Mo-O $\mathrm{O}$ at $790 \mathrm{~cm}^{-1}$ ) in the fingerprint area (Figure S3),[24] which indicates that the $\mathrm{PMo}_{12} \mathrm{O}_{40}{ }^{3-}$ in the nanocomposites remain the Keggin structure. The absorption bands of CDS-PMo $12 @ \mathrm{PVP}_{0.5}$ and CDS-PMo12@PVP 1 arising from the $\mathrm{PMo}_{12} \mathrm{O}_{40}{ }^{3-}$ are shifted in position, which demonstrates that the bonds of the $\mathrm{PMo}_{12} \mathrm{O}_{40}{ }^{3-}$ are either strengthened or weakened, owing to the interaction between the $\mathrm{N}$ of the PVP and $\mathrm{O}$ atom of the $\mathrm{PMo}_{12} \mathrm{O}_{40}{ }^{3-}$. Besides, the resonance peak of C-O (at $1643 \mathrm{~cm}^{-1}$ ) shows no change, and the peak of the $\mathrm{N}-\mathrm{OH}$ complex (at $1288 \mathrm{~cm}^{-1}$ ) disappears as compared with the PVP spectrum. These changes in the spectrum of CDS-PMo ${ }_{12} @ \mathrm{PVP}_{1}$ suggest the coordination between $\mathrm{N}$ and $\mathrm{PMo}_{12} \mathrm{O}_{40}{ }^{3-}$ as the main reaction, while the reaction between $\mathrm{O}$ and $\mathrm{PMo}_{12} \mathrm{O}_{40}{ }^{3-}$ is less significant. Overall, these results demonstrate PVP was successfully anchored to the $\mathrm{PMo}_{12}$-based NPs. 
b

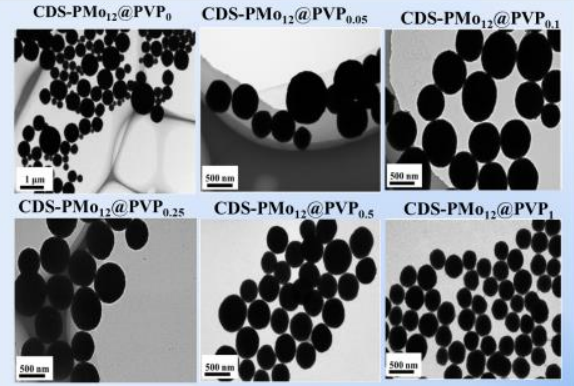

e

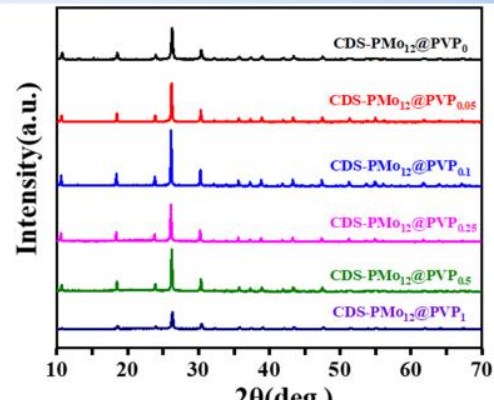

f

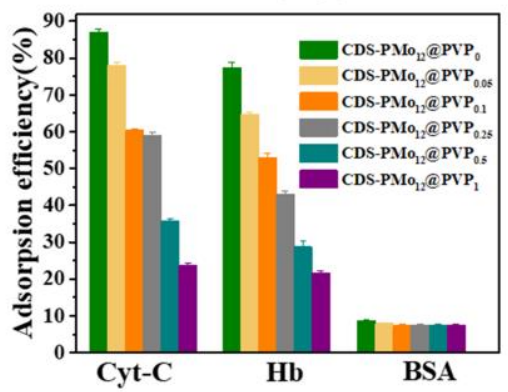

g

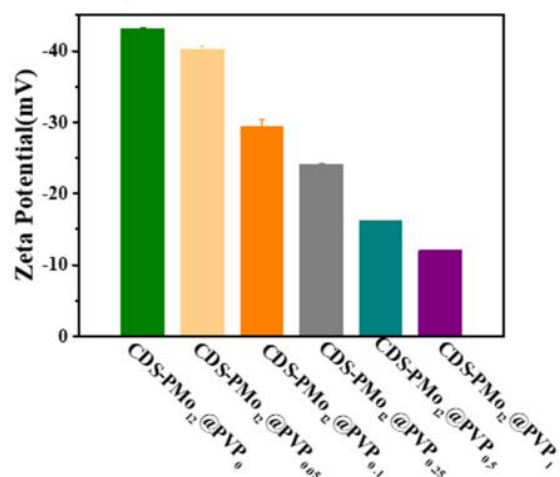

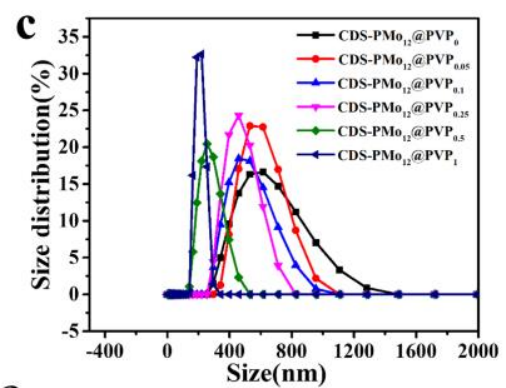

a

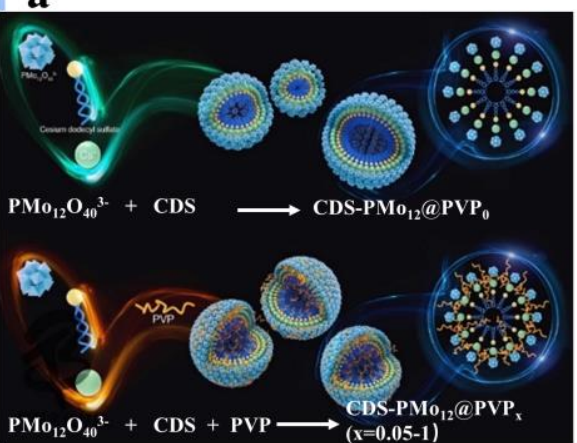

h CDS-PMo $_{12} @ \mathrm{PVP}_{0} /$ proteins

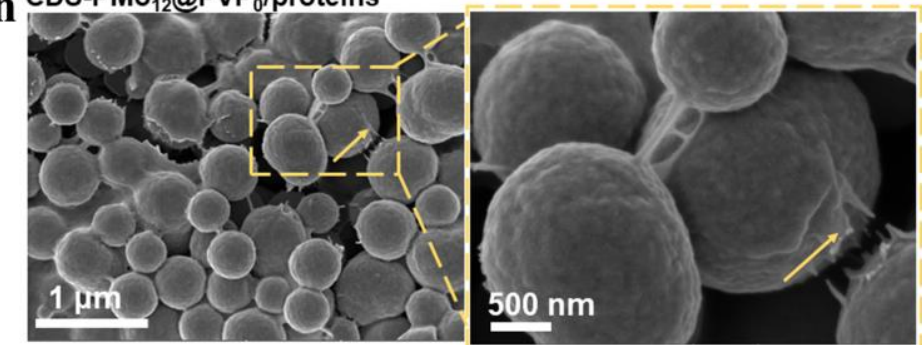

CDS-PMo ${ }_{12} @ \mathrm{PVP}_{1} /$ proteins

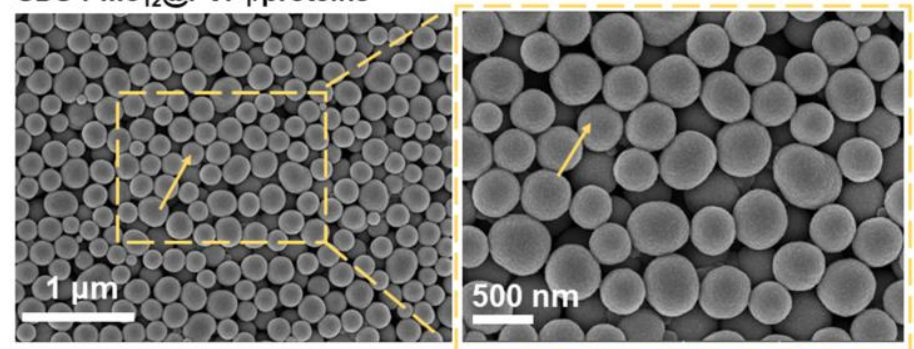

Figure 1 CDS-PMo ${ }_{12} @ \mathrm{PVP}_{\mathrm{x}}(\mathrm{x}=0 \sim 1)$ NPs synthesis, characterization, and protein adsorption efficiency. (a) Schematic illustration of the formation process of CDS-PMo ${ }_{12} @ \mathrm{PVP}_{\mathrm{x}}(\mathrm{x}=0 \sim 1)$ NPs. (b) TEM images of CDS-PMo ${ }_{12} @ \mathrm{PVP}_{\mathrm{x}}(\mathrm{x}=0 \sim 1)$ NPs. (c) The size distribution of CDS-PMo ${ }_{12} @ \mathrm{PVP}_{\mathrm{x}}(\mathrm{x}=0 \sim 1) \mathrm{NPs}$ characterized by DLS. (d) XRD patterns of the CDS-PMo ${ }_{12} @ \mathrm{PVP}_{\mathrm{x}}(\mathrm{x}=0 \sim 1)$ NPs. (e) HAADF-STEM image of CDS-PMo ${ }_{12} @ \mathrm{PVP}_{1} \mathrm{NPs}$ and corresponding $\mathrm{O}, \mathrm{Mo}, \mathrm{P}, \mathrm{Cs}, \mathrm{C}$, and $\mathrm{N}$ elemental mapping. (f) The adsorption efficiency of CDS-PMo ${ }_{12} @ \mathrm{PVP}_{\mathrm{x}}(\mathrm{x}=0 \sim 1) \mathrm{NPs}$ towards three types of proteins. (g) the Zeta-potential of CDS-PMo ${ }_{12} @ \mathrm{PVP}_{\mathrm{x}}(\mathrm{x}=0 \sim 1)$ NPs (B-R buffer, pH=6). (h) SEM images of CDS-PMo ${ }_{12} @ \mathrm{PVP}_{0}$ 
141 and CDS-PMo $12 @ \mathrm{PVP}_{1}$ NPs after absorbing the mixed solution of three types of proteins.

142 Arrows indicate that the obvious protein coating induce rough surfaces of 143 CDS-PMo ${ }_{12} @ \mathrm{PVP}_{0}$ NPs and very few protein coating on the surface of CDS-PMo ${ }_{12} @ \mathrm{PVP}_{1}$ 144 NPs.

145 Protein adsorption behaviors on the CDS-PMo12@PVP $\mathbf{x}(\mathbf{x}=\mathbf{0} \sim 1)$ NPs.

$146 \mathrm{Cyt}-\mathrm{C}, \mathrm{Hb}$, and BSA were chosen as representatives of basic, neutral, and acidic proteins to evaluate adsorption behaviors of the CDS-PMo ${ }_{12} @ \mathrm{PVP}_{\mathrm{x}}(\mathrm{x}=0 \sim 1)$ NPs. Figure S4 summarized the protein adsorption performance on CDS-PMo ${ }_{12} @ \mathrm{PVP}_{0} \mathrm{NPs}$. The optimized adsorption conditions from preliminary experiments (adsorption time: $20 \mathrm{~min}$, temperature: $25^{\circ} \mathrm{C}$, B-R buffer concentration: $0.04 \mathrm{~mol} \mathrm{~L}^{-1}$ ) were applied to the adsorption study of $(\mathrm{Hb} / \mathrm{Cyt}-\mathrm{C})$ on CDS-PMo ${ }_{12} @ \mathrm{PVP}_{\mathrm{x}}(\mathrm{x}=0 \sim 1)$ NPs were gradually decreased when PVP content increased, while no obvious alteration in the adsorption efficiencies of BSA was observed (Figure 1f). Zeta-potential measurements illustrate that the neutral amphiphilic PVP polymer neutralizes the electronegativity of the CDS-PMo12@PVP $\mathrm{PPs}_{0}$ (Figure 1g), limiting the adsorption of positively charged $\mathrm{Hb} / \mathrm{Cyt}-\mathrm{C}$ proteins on the CDS-PMo ${ }_{12} @ \mathrm{PVP}_{\mathrm{x}}(\mathrm{x}=0.05 \sim 1)$ NPs at $\mathrm{pH}$ 6, hence explains the declined adsorption efficiencies. On the other hand, BSA $(\mathrm{pI}=4.7)$ is negatively charged at $\mathrm{pH} 6$, and virtually no retention of BSA occurs on the negatively charged CDS-PMo12@PVP 0 NPs surfaces. The SEM images show obvious protein coatings on the surface of CDS-PMo12@ $\mathrm{PVP}_{0}$ NPs and barely any retention on the surface of CDS-PMo ${ }_{12} @ \mathrm{PVP}_{1}$ NPs (Figure 1h) after absorbing the mixed solution of three types of proteins. Our results confirm that PVP in the nanocomposites regulates the chemical 
composition, particle size, surface physicochemical property, and consequently, protein adsorption efficiency.

\section{The binding process and mechanism of protein adsorption on PMo12-based NPs.}

To explore the effect of PVP on the binding kinetics and thermodynamic process of protein/PMo ${ }_{12}$-based NPs complexes formation, we investigated the protein fluorescence quenching process upon binding to (CDS-PMo ${ }_{12} @ \mathrm{PVP}_{\mathrm{x}}(\mathrm{x}=0,1)$ NPs quenchers.[31] First, we incubated proteins with different concentrations of CDS-PMo ${ }_{12} @ \mathrm{PVP}_{\mathrm{x}}(\mathrm{x}=0,1) \mathrm{NPs}$ ranging from 0 to $15 \mu \mathrm{M}$ at $298 \mathrm{~K}$ and $310 \mathrm{~K}$ for $10 \mathrm{~min}$, respectively. Then we measured the intrinsic fluorescence intensity (here tryptophan residue of $\mathrm{Cyt}-\mathrm{C}, \mathrm{Hb}$, and BSA proteins) before and after incubation with CDS-PMo $\mathrm{PM}_{12} @ \mathrm{PVP}_{\mathrm{x}}(\mathrm{x}=0,1) \mathrm{NPs}$ and analyzed fluorescence quenching data by the Stern-Volmer (S-V) equation (Eq. (1)).[32]

$$
\frac{F_{0}}{F}=1+K_{S V}[Q]=1+k_{q} \tau_{0}[Q]
$$

where $\mathrm{F}_{0}$ and $\mathrm{F}$ are the fluorescence intensities of proteins in the absence and presence of quencher (here CDS-PMo12@ $\left.\mathrm{PVP}_{\mathrm{x}}(\mathrm{x}=0,1) \mathrm{NPs}\right) ; K_{S V}$ is the $\mathrm{S}-\mathrm{V}$ quenching constant; [Q] is the total concentration of the quencher; $k_{q}$ is the quenching rate constant, and $\tau_{0}$ is the fluorophore average lifetime in the absence of quencher (for biomolecules is $10^{-8} \mathrm{~s}$ ). The fluorescence spectra of proteins incubating with CDS-PMo12@ $\mathrm{PVP}_{\mathrm{x}}(\mathrm{x}=0,1)$ and $\mathrm{S}-\mathrm{V}$ plot are displayed in Figure 2b-d and Figure S5-7. The S-V plot of proteins binding to CDS-PMo ${ }_{12} @ \mathrm{PVP}_{\mathrm{x}}(\mathrm{x}=0,1) \mathrm{NPs}$ shows a positive deviation from a linear S-V relation (Figure $2 \mathrm{~d}$ and Figure S7). The positive deviation of the slope is attributed to the simultaneous presence of dynamic and static quenching.[33-37] 
A modified S-V equation (Eq. (2)) was used to calculate the effective S-V quenching constant $\left(K_{\mathrm{sv}}\right)$ and the quenching rate constant $\left(k_{\mathrm{q}}\right)$ of the interaction of proteins and CDS-PMo ${ }_{12} @ \mathrm{PVP}_{\mathrm{x}}(\mathrm{x}=0,1) \mathrm{NPs}$.

$$
\frac{F_{0}}{\Delta F}=\frac{F_{0}}{F_{0}-F}=\frac{1}{f_{a} K_{s v}} \frac{1}{[Q]}+\frac{1}{f_{a}}
$$

In which $f_{\mathrm{a}}$ is the mole fraction of accessible fluorescence, and $K_{s v}$ is the effective S-V quenching constant for the accessible fluorophores. The dependence of $\mathrm{F}_{0} /\left(\mathrm{F}_{0}-\mathrm{F}\right)$ vs $[Q]^{-1}$, should be linear with the slope of $(f a K s v)^{-1}$, whereas the value $f a^{-1}$ is fixed on the ordinate. Therefore, the effective quenching constant $K s v$ is a quotient of the ordinate $f a^{-1}$ and the slope $(f a K s v)^{-1}$. The modified S-V plot of proteins binding to CDS-PMo ${ }_{12} @ \mathrm{PVP}_{\mathrm{x}}(\mathrm{x}=0,1)$ NPs are shown in Figure 2e and Figure S7. The values of $K_{s v}$ for BSA/CDS-PMo $\mathrm{Mo}_{12} @ \mathrm{PVP}_{0}$, Hb/CDS-PMo ${ }_{12} @ \mathrm{PVP}_{0}$, Cyt-C/CDS-PMo ${ }_{12} @ \mathrm{PVP}_{1}$, and Hb/CDS-PMo ${ }_{12} @ \mathrm{PVP}_{1}$ complexes are increased with the temperature (Table 1), indicating a dynamic process exists in those complexes. The Ksv of Cyt-C/CDS-PMo ${ }_{12} @ \mathrm{PVP}_{0}$ and BSA/CDS-PMo ${ }_{12} @ \mathrm{PVP}_{1}$ complexes are correlated inversely with temperature, indicating the proteins quenching mechanism is initiated by static quenching. However, the $K q$ of the proteins/CDS-PMo $\mathrm{o}_{12} @ \mathrm{PVP}_{\mathrm{x}}(\mathrm{x}=0,1)$ complexes are higher than the maximal dynamic quenching constant $\left(2 \times 10^{10} \mathrm{M}^{-1} \mathrm{~s}^{-1}\right)$, revealing the main quenching mechanism for proteins binding to CDS-PMo $\mathrm{P}_{12} @ \mathrm{PVP}_{\mathrm{x}}(\mathrm{x}=0,1)$ NPs is static quenching.[38] 


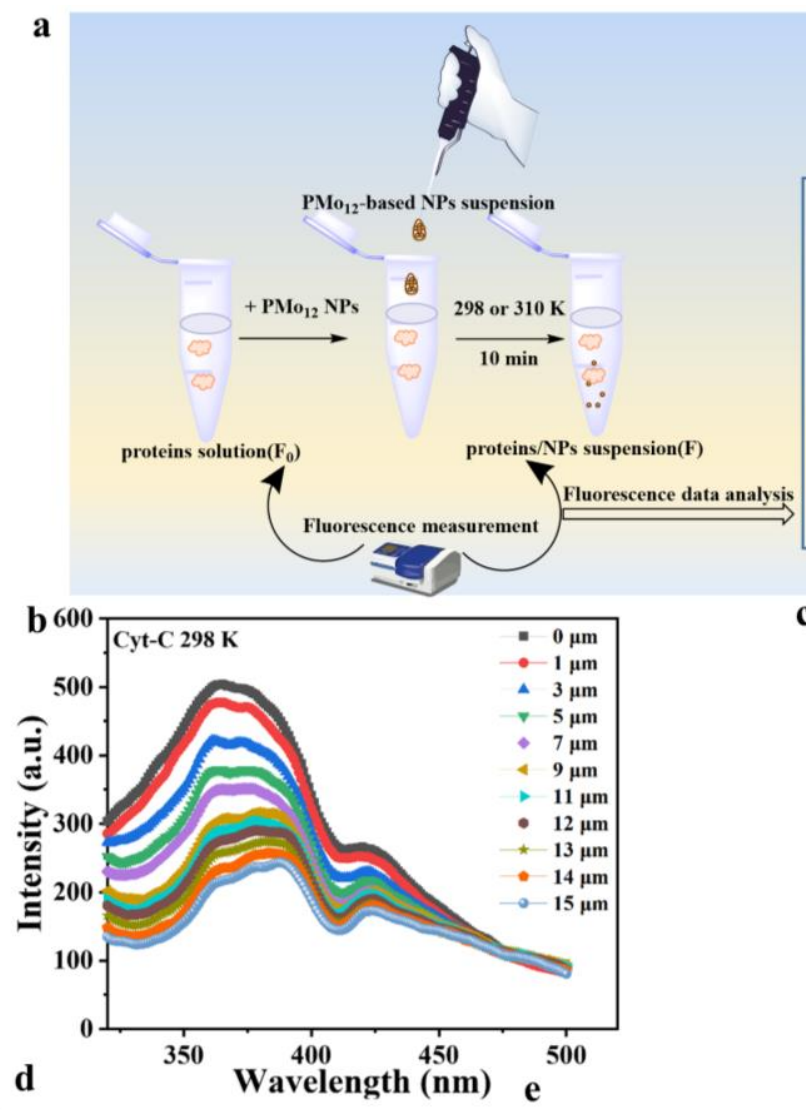

\section{Equations}

(1) $\frac{F_{0}}{F}=1+K_{S V}[Q]=1+k_{q} \tau_{0}[Q]$

(2) $\frac{F_{0}}{\Delta F}=\frac{F_{0}}{F_{0}-F}=\frac{1}{f_{a} K_{s v}} \frac{1}{[Q]}+\frac{1}{f_{a}}$

(3) $\log \left[\frac{F_{0}-F}{F}\right]=\log K_{a}+n \log [Q]$

(4) $\ln K_{a}=-\frac{\Delta H^{0}}{R T}+\frac{\Delta S^{0}}{R}$

(5) $\Delta G^{0}=\Delta H^{0}-T \Delta S^{0}=-R T \ln K_{a}$
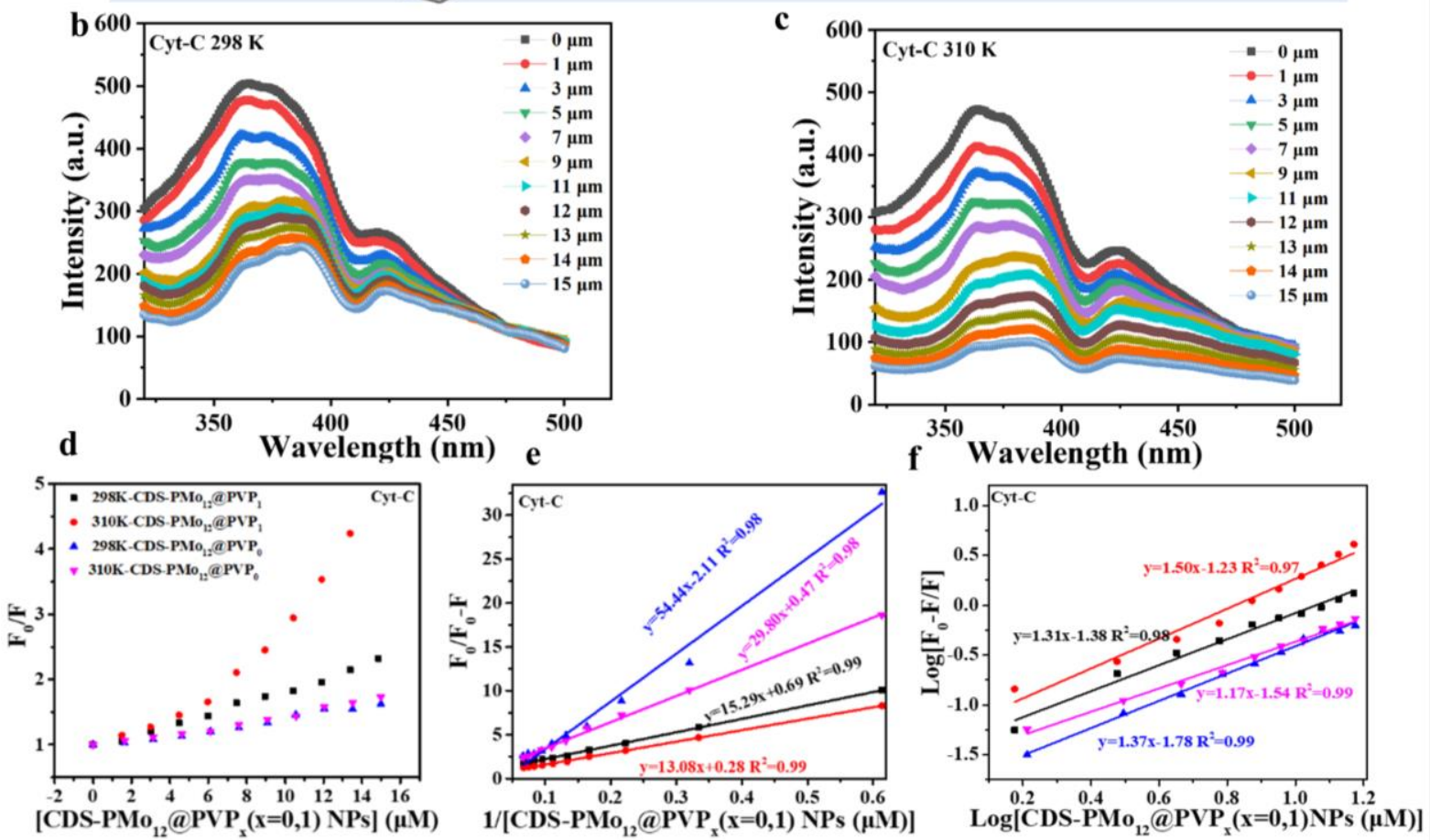

Figure 2 The fluorescence quenching studies of proteins in the presence of CDS-PMo ${ }_{12} @ \mathrm{PVP}_{\mathrm{x}}(\mathrm{x}=0,1)$ NPs. (a) The fluorescence quenching experiment and corresponding calculation equation. (b-c) The fluorescence emission spectra of Cyt-C in the absence and presence of CDS-PMo ${ }_{12} @ \mathrm{PVP}_{0} \mathrm{NPs}$ at $298 \mathrm{~K}$ and $310 \mathrm{~K}$, respectively. The concentration of Cyt-C is fixed as $5 \mu \mathrm{M}$; the concentrations of CDS-PMo ${ }_{12} @ \mathrm{PVP}_{0} \mathrm{NPs}$ is changed from 0-15 $\mu \mathrm{M}$. (d) Stern-Volmer plot of Cyt-C intrinsic fluorescence quenching by CDS-PMo ${ }_{12} @ \mathrm{PVP}_{\mathrm{x}}(\mathrm{x}=0,1)$ NPs. (e) The modified Stern-Volmer plot of Cyt-C intrinsic fluorescence quenching by CDS-PMo ${ }_{12} @ \mathrm{PVP}_{\mathrm{x}}(\mathrm{x}=0,1)$ NPs. (f) The double logarithmic plot 
211 of Cyt-C intrinsic fluorescence quenching by CDS-PMo ${ }_{12} @ \mathrm{PVP}_{\mathrm{x}}(\mathrm{x}=0,1) \mathrm{NPs}$ at $298 \mathrm{~K}$ and $212310 \mathrm{~K}$, respectively. The number of binding sites $(n)$, and binding constant $\left(K_{\mathrm{a}}\right)$ were obtained according to the double logarithmic equation (Eq. (3)).[39]

$$
\log \left[\frac{F_{0}-F}{F}\right]=\log K_{a}+n \log [Q]
$$

The double logarithmic plot of proteins binding to CDS-PMo ${ }_{12} @ \mathrm{PVP}_{\mathrm{x}}(\mathrm{x}=0,1)$ NPs are shown in Figure $2 \mathrm{f}$ and Figure S7. By linear fitting for the the double logarithmic plot, the values of $n$ and $K_{\mathrm{a}}$ are obtained from the slope and Y-axis intercept, respectively. The value of $n$ for Cyt-C/Hb binding to $\mathrm{CDS}-\mathrm{PMo}_{12} @ \mathrm{PVP}_{1} \mathrm{NPs}$ is smaller than that binding to CDS-PMo ${ }_{12} @ \mathrm{PVP}_{0}$ NPs (Table 1). The results suggest that the introduction of PVP reduces for $\mathrm{Cyt}-\mathrm{C} / \mathrm{Hb}$ binding to $\mathrm{CDS}-\mathrm{PMo}_{12} @ \mathrm{PVP}_{0} \mathrm{NPs}$ have no apparent increase with temperature (Table 1), combined with the static quenching mechanism, we cross-verified the stable complex formation between $\mathrm{Cyt}-\mathrm{C} / \mathrm{Hb}$ and CDS-PMo ${ }_{12} @ \mathrm{PVP}_{0}$ NPs. Conversely, with the temperature rising, the value of $K_{a}$ increases largely for BSA/CDS-PMo ${ }_{12} @ \mathrm{PVP}_{0}$ complex (Table 1), suggesting the BSA/CDS-PMo12@PVP complex is unstable.[40-42] $K_{\mathrm{a}}$ is dependent on temperature, which indicates that the protein formation on CDS-PMo $12 @ \mathrm{PVP}_{\mathrm{x}}(\mathrm{x}=0,1) \mathrm{NPs}$ is a thermodynamic process. Enthalpy change $\left(\Delta H^{0}\right)$, entropy change $\left(\Delta S^{0}\right)$, and free energy change $\left(\Delta G^{0}\right)$ are used to further characterize the driving interaction force between CDS-PMo ${ }_{12} @ \mathrm{PVP}_{\mathrm{x}}(\mathrm{x}=0,1)$ NPs and three types of proteins. The values of $\Delta S^{0}$ and $\Delta H^{0}$ were calculated from the slope and the intercept, respectively, by 
fitting linearly to the plot of $\ln K_{a}$ Vs. 1/T according to the Van Hoff equation Eq. (4), whereas the $\Delta G^{0}$ value was calculated from Eq. (5).

$$
\ln K_{a}=-\frac{\Delta H^{0}}{R T}+\frac{\Delta S^{0}}{R}
$$

Where $K_{\mathrm{a}}$ is the binding constant at the corresponding temperature $(T)$ and $R$ is the gas constant. $\Delta S^{0}$ and $\Delta H^{0}$ are determined from the linear Van't Hoff plots. $\Delta G^{0}$ is estimated from the following equation (Eq. (5))[43]:

$$
\Delta G^{0}=\Delta H^{0}-T \Delta S^{0}=-R T \ln K_{a}
$$

According to the views of Timasheff,[44] the positive values of $\Delta S^{0}$ and $\Delta H^{0}$ indicate that hydrophobicity plays a major role in protein interaction with CDS-PMo12@PVP $\mathrm{NPs}_{12}$ (Table 1). A negative value of $\Delta H^{0}$ and positive values of $\Delta S^{0}$ indicate that electrostatic forces are the major forces between the CDS-PMo ${ }_{12} @ \mathrm{PVP}_{1}$ and proteins (Table 1). The negative sign of the $\Delta G^{0}$ proves that the CDS-PMo ${ }_{12} @ \mathrm{PVP}_{\mathrm{x}}(\mathrm{x}=0,1)$ NPs interact with three types of proteins are spontaneous (Table 1). 
Table 1 The adsorption kinetics and thermodynamic parameters of the protein/PMo12-based

252 NPs complexes obtained from fluorescence quenching data.

\begin{tabular}{|c|c|c|c|c|c|c|c|c|c|}
\hline $\begin{array}{l}\text { Proteins/PMo } \\
\text { NPs }\end{array}$ & $\begin{array}{c}\text { Temp } \\
\text { (K) }\end{array}$ & Ksv & $\begin{array}{c}K q \\
\left(\times 10^{12}\right)\end{array}$ & $\mathrm{fa}$ & $n$ & $\begin{array}{c}K_{\mathrm{a}} \\
\left(\times 10^{6} \mathrm{M}^{-1}\right)\end{array}$ & $\begin{array}{c}\Delta \mathbf{G}^{0} \\
(\mathbf{k J} / \mathrm{mol})\end{array}$ & $\underset{(\mathbf{k J} / \mathrm{mol})}{\Delta \mathrm{H}^{0}}$ & $\underset{(\mathrm{J} / \mathrm{mol} \cdot \mathrm{K}}{\Delta \mathbf{S}^{0}}$ \\
\hline \multirow[t]{2}{*}{$\begin{array}{c}\text { BSA/CDS- } \\
\text { PMo }_{12} @ P^{2} P_{0}\end{array}$} & 298 & 0.085 & 8.46 & 0.476 & 0.94 & 0.035 & -25.97 & 144.47 & 571.66 \\
\hline & 310 & 0.597 & 59.7 & 0.625 & 0.54 & 0.338 & -32.83 & & \\
\hline \multirow[t]{2}{*}{$\begin{array}{c}\mathrm{Hb} / \mathrm{CDS}- \\
\mathrm{PMo}_{12} @ \mathrm{PVP}_{0}\end{array}$} & 298 & 0.013 & 1.4 & 2.381 & 1.2 & 0.028 & -25.46 & 19.01 & 149.17 \\
\hline & 310 & 0.039 & 3.9 & 1.099 & 1.1 & 0.038 & -27.31 & & \\
\hline \multirow[t]{2}{*}{$\begin{array}{l}\text { Cyt-C/CDS- } \\
\text { PMo }_{12} @ P^{2} P_{0}\end{array}$} & 298 & 0.045 & 4.52 & 1.449 & 1.3 & 0.04 & -26.31 & 22.14 & 162.5 \\
\hline & 310 & 0.021 & 2.14 & 3.571 & 1.5 & 0.06 & -28.26 & & \\
\hline \multirow[t]{2}{*}{$\begin{array}{c}\text { BSA/CDS- } \\
\mathrm{PMo}_{12} @ \mathrm{PVP}_{1}\end{array}$} & 298 & 0.064 & 6.42 & 0.303 & 0.78 & 0.016 & -24.08 & -8.93 & 50.83 \\
\hline & 310 & 0.005 & 0.531 & 3.333 & 0.71 & 0.014 & -24.69 & & \\
\hline \multirow[t]{2}{*}{$\begin{array}{c}\mathrm{Hb} / \mathrm{CDS}- \\
\mathrm{PMo}_{12} @ \mathrm{PVP}_{1}\end{array}$} & 298 & 0.012 & 1.2 & 2.439 & 0.91 & 0.019 & -24.48 & -2.87 & 72.48 \\
\hline & 310 & 0.032 & 3.3 & 0.971 & 0.83 & 0.018 & -25.35 & & \\
\hline \multirow[t]{2}{*}{$\begin{array}{l}\text { Cyt-C/CDS- } \\
\text { PMo }_{12} @ P^{2} P_{1}\end{array}$} & 298 & 0.004 & 4.04 & 4.545 & 0.98 & 0.032 & -25.74 & -7.35 & 61.67 \\
\hline & 310 & 0.016 & 1.58 & 2.128 & 1.1 & 0.028 & -26.48 & & \\
\hline
\end{tabular}

254 Molecular docking study of CDS-PMo12@PVP $\mathbf{x}(\mathbf{x}=\mathbf{0 , 1})$ NPs and Protein interactions.

The fluorescence quenching experiments indicate that hydrophobicity is the main driving forces for CDS-PMo12@ $\mathrm{PVP}_{0}$ binding to three types of proteins, and while the 257 electrostatic interactions are identified as the main forces between proteins and 258 CDS-PMo $12 @ \mathrm{PVP}_{1}$ NPs. During CDS-PMo12@ $\mathrm{PVP}_{0}$ interacts with the proteins, the primary 259 force is hydrophobic and the secondary forces is electrostatic (Figure 3a). Molecular 260 docking[45] results show that CDS-PMo12@PVP $\mathrm{P}_{1}$ binds with $\mathrm{Cyt}-\mathrm{C}, \mathrm{Hb}$, and BSA mainly 261 through electrostatic interaction, but also Van der Waals force as the second action force 262 (Figure 3b). 
The contact surface area (CSA) and binding energy between the three model proteins and CDS-PMo12@PVP $\mathrm{PV}_{\mathrm{x}}(\mathrm{x}=0,1) \mathrm{NPs}$ were calculated using molecular docking.[45] As shown in Figure 3c-d, the CSA of proteins on CDS-PMo ${ }_{12} @ \mathrm{PVP}_{0}$ is larger than that on CDS-PMo ${ }_{12} @ \mathrm{PVP}_{1}$. Importantly, the CSA of Cyt-C is larger than that of $\mathrm{Hb} / \mathrm{BSA}$ on CDS-PMo ${ }_{12} @ \mathrm{PVP}_{\mathrm{x}}(\mathrm{x}=0,1)$ NPs. The binding energy of the three model proteins binding to CDS-PMo12@ $\mathrm{PVP}_{0}$ is smaller than that binding to CDS-PMo $12 @ \mathrm{PVP}_{1}$, thus confirming a higher affinity of three model proteins to CDS-PMo ${ }_{12} @ \mathrm{PVP}_{0} \mathrm{NPs}_{\text {than }} \mathrm{CDS}_{\mathrm{PM}} \mathrm{PM}_{12} @ \mathrm{PVP}_{1}$ NPs. 


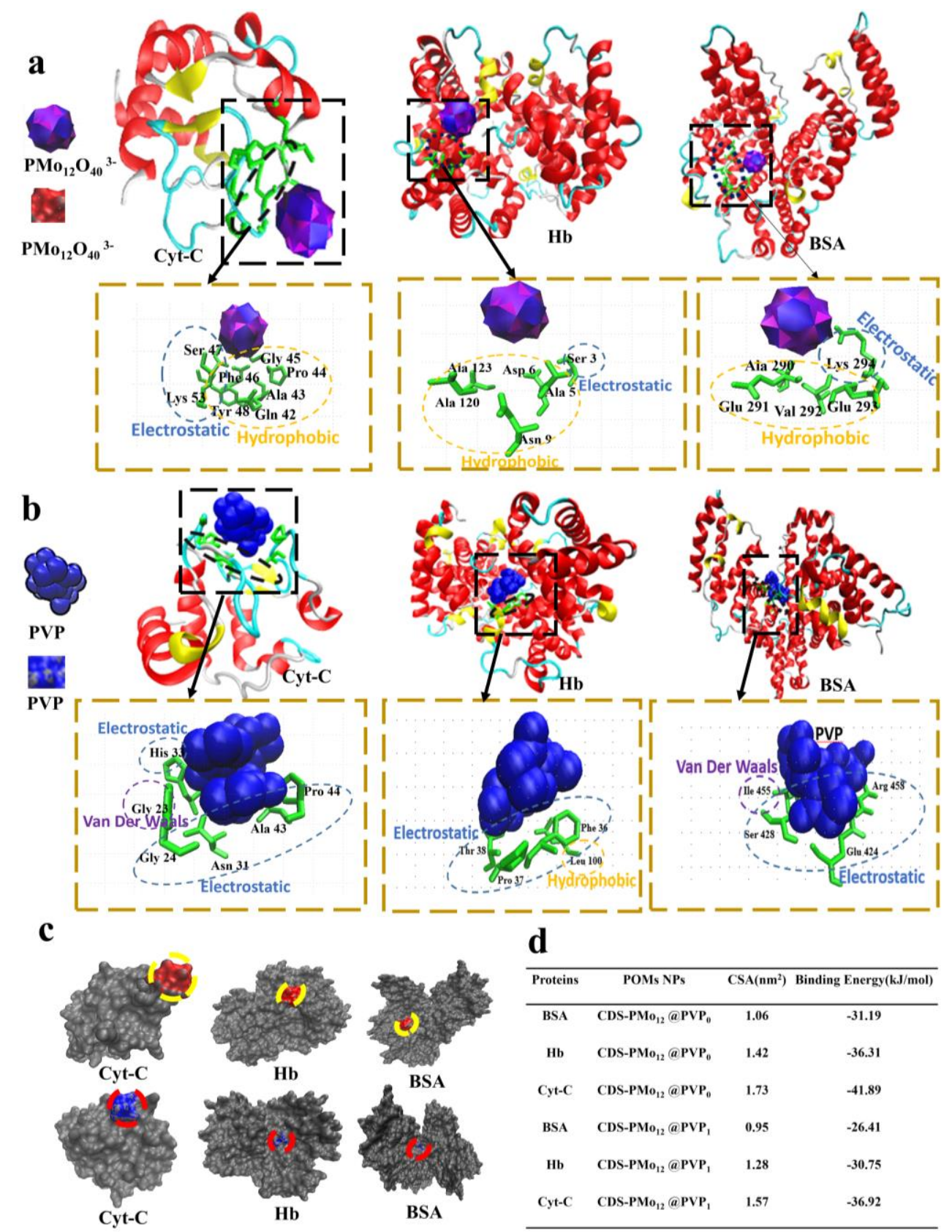

Figure 3 The molecular docking computational results of the interaction of $\mathrm{Cyt}-\mathrm{C}, \mathrm{Hb}$, and BSA with CDS-PMo ${ }_{12} @ \mathrm{PVP}_{\mathrm{x}}(\mathrm{x}=0,1)$ NPs. The structure snapshots of Cyt-C, Hb, and BSA adsorption on (a) CDS-PMo ${ }_{12} @ \mathrm{PVP}_{0}$ and (b) CDS-PMo ${ }_{12} @ \mathrm{PVP}_{1}$ NPs, respectively. (c) The CSA visualization of the three model proteins binding to the CDS-PMo12@PVP NPs (the upper row) and binding to CDS-PMo,12@PVP ${ }_{1}$ NPs (the lower row). (d) The value of calculated CSA and the binding energy of three model proteins on CDS-PMo ${ }_{12} @ \mathrm{PVP}_{\mathrm{x}}$ $(\mathrm{x}=0,1)$ NPs. 

formation

The CDS-PMo $12 @ \mathrm{PVP}_{\mathrm{x}}(\mathrm{x}=0 \sim 1) \mathrm{NPs}$ were then incubated in human plasma to acquire a stable protein corona, followed by centrifugation of NPs from unbound proteins. The plasma proteins in the protein corona were then digested, purified, and eluted. The resulting peptides from the NPs-bound corona were analyzed by LC-MS/MS coupled with label-free quantification in data-dependent acquisition mode (DDA)[46] (Figure 4a, see details in Methods).

CDS-PMo ${ }_{12} @ \mathrm{PVP}_{0}$, CDS-PMo $12 @ \mathrm{PVP}_{0.05}$, CDS-PMo ${ }_{12} @ \mathrm{PVP}_{0.1}$, CDS-PMo ${ }_{12} @ \mathrm{PVP}_{0.25}$, CDS-PMo $\mathrm{P}_{12} @ \mathrm{PVP}_{0.5}$, and CDS-PMo $\mathrm{P}_{12} @ \mathrm{PVP}_{1}$ NPs facilitated the quantification of $~ 300$ protein groups across 18 samples (triplicate measurements of the six NPs) (Figure 4b). Compared to the protein groups on CDS-PMo ${ }_{12} @ \mathrm{PVP}_{0}(383)$, those on CDS-PMo ${ }_{12} @ \mathrm{PVP}_{0.05}$, CDS-PMo ${ }_{12} @ \mathrm{PVP}_{0.1}$, CDS-PMo ${ }_{12} @ \mathrm{PVP}_{0.25}$, CDS-PMo ${ }_{12} @ \mathrm{PVP}_{0.5}$, and CDS-PMo $\mathrm{Po}_{12} @ \mathrm{PVP}_{1}$ decreased to $372,355,340,317$, and 271, respectively (Figure 4b), further supporting that the PVP addition indeed quantitatively decreases the protein adsorption. To determine the triplicate tests variability, we further calculated the coefficient of variation (CV) for protein group quantification using DDA. The coefficient of variation $(\mathrm{CV})$ of triplicate tests were $9.64 \%, 21.3 \%, 7.74 \%, 10.32 \%, 15.48 \%$ and $14.35 \%$ (on average $13.14 \%$ ) for CDS-PMo ${ }_{12} @ \mathrm{PVP}_{0}, \quad C D S-\mathrm{PMo}_{12} @ \mathrm{PVP}_{0.05}, \quad C D S-\mathrm{PMo}_{12} @ \mathrm{PVP}_{0.1}, \quad C D S-\mathrm{PMo}_{12} @ \mathrm{PVP}_{0.25}$, CDS-PMo12@PVP 0.5 , and CDS-PMo12@PVP, respectively (Figure 4c). The number of protein groups with $\mathrm{CVs}<20 \%$ agrees with the range of the precision determined in previous 
studies.[47,48]To explore how the PVP influences the plasma protein corona of the $\mathrm{PMo}_{12}$-based NPs, we further compared the plasma protein corona compositions formed on the CDS-PMo12@ $\mathrm{PVP}_{0}$ and CDS-PMo ${ }_{12} @ \mathrm{PVP}_{1} \mathrm{NPs}$ by statistical analysis. Compared to CDS-PMo ${ }_{12} @ \mathrm{PVP}_{0}$ protein corona compositions, a total of 76 significant differentially proteins (with adjusted P-value < 0.01) are identified for CDS-PMo12@ $\mathrm{PVP}_{1}$ protein corona composition, among which 55 proteins are up-regulated and 21 proteins are down-regulated (Figure 4d). The relative abundance of differential proteins is shown in the heatmap (Figure S7). The top ten up-regulated proteins and down-regulated proteins are listed in Table S1. Apolipoprotein, Plasma protease $\mathrm{C} 1$ inhibitor, and $\mathrm{IgG}$ Fc-binding protein $\mathrm{OS}=$ Homo sapiens human corona suggests, apolipoprotein is the second most abundant class of proteins, proposed to have dysoponic activity (i.e. favor long blood circulation).[28] LC/MS-MS analysis results further verified that PVP grafting on the PMo12-based NPs successfully mitigates the plasma protein corona formation and apolipoproteins adsorption on CDS-PMo ${ }_{12} @ \mathrm{PVP}_{1}$ NPs could potentially extend blood circulation time and permit better bio-sustainability. 
a
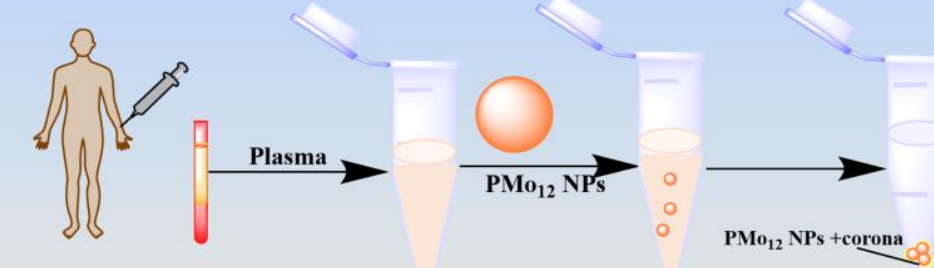

Plasma diluent

Incubation

Centrifugation
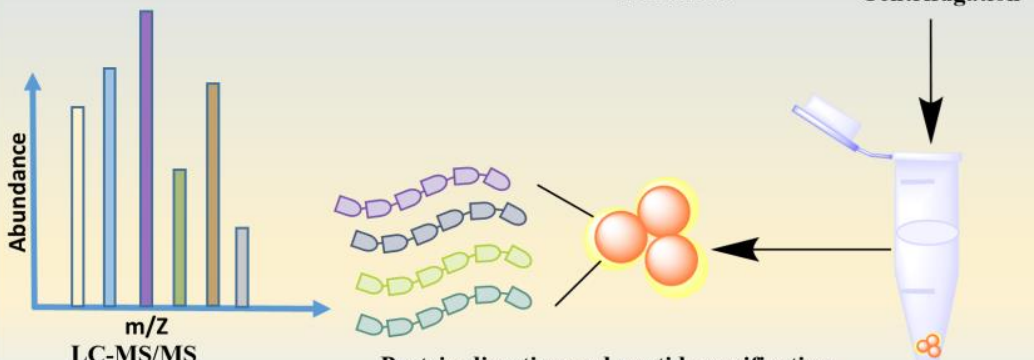

LC-MS/MS

Protein digestion and peptide purification

8

Washing and

centrifugation( 3 times)

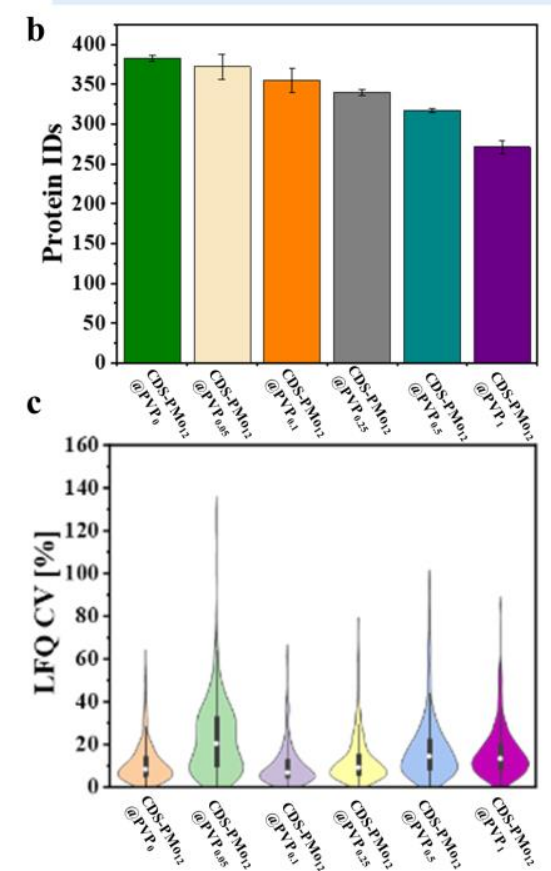

d

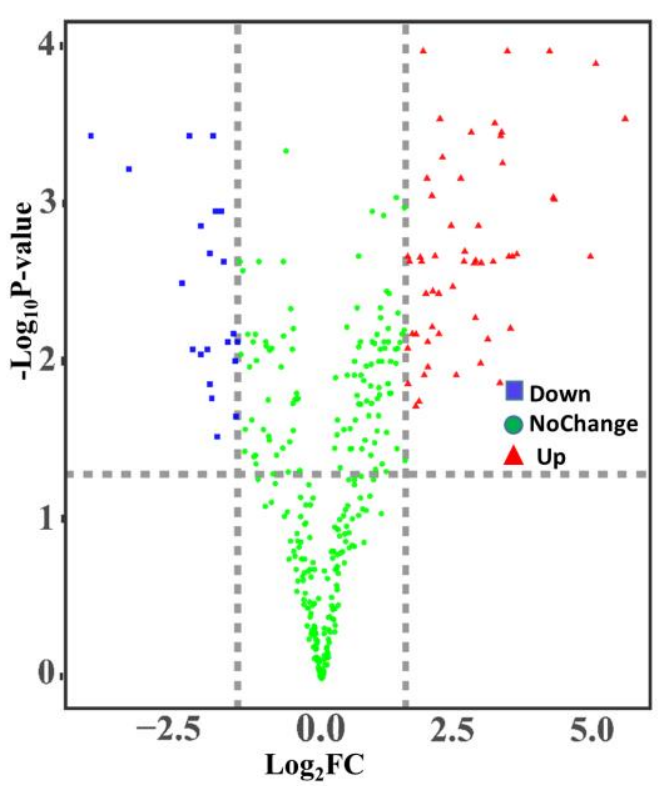

Figure 4 Plasma Proteomics characterization of the CDS-PMo ${ }_{12} @ \mathrm{PVP}_{\mathrm{x}}(\mathrm{x}=0 \sim 1) \mathrm{NPs}$. (a) The plasma protein corona formation process of CDS-PMo ${ }_{12} @ \mathrm{PVP}_{\mathrm{x}}(\mathrm{x}=0 \sim 1) \mathrm{NPs}$, and Plasma Proteomics identified by LC-MS/MS. (b) The number of plasma protein groups identified by LC-MS/MS from the protein corona of the CDS-PMo ${ }_{12} @ \mathrm{PVP}_{\mathrm{x}}(\mathrm{x}=0 \sim 1) \mathrm{NPs}$, standard deviation across three assay replicates are shown as error bar. (c) CV\% for precision evaluation of three assay replicates. Inner boxplots report the 25\% (lower hinge), 50\%, and $75 \%$ quantiles (upper hinge). Whiskers indicate observations outside hinge $\pm 1.5^{*}$ 
interquartile range (IQR). Violin plots capture all data points. (d) Volcano plot of the correlations between the P-value and fold change (FC), the normalized abundance ratio of CDS-PMo12@PVP $/$ CDS-PMo $12 @ \mathrm{PVP}_{0}$ was used for the calculation the FC.(number of parallel $=3$, P-values were calculated with student's t-test).

\section{CONCLUSIONS}

The PMo 12 -based NPs are reported to deliver promising anti-tumor biological activities by the virtue of their desired diversity in structures and properties. However, nanomaterials' effective nanomedicine applications are hampered by limited understanding and control over their interactions with complex biological systems. Here, we adopted PVP polymer to modulate the size and surface functionality of $\mathrm{PMo}_{12}$-based NPs. PVP successfully decreased the protein adsorption on the surface of CDS-PMo ${ }_{12} @ \mathrm{PVP}_{\mathrm{x}}(\mathrm{x}=0 \sim 1) \mathrm{NPs}$. On the assessment of the interaction mechanism between engineering $\mathrm{PMo}_{12}$-based NPs and proteins (base, neutral and acid proteins), the steady-state fluorescence quenching results revealed the interaction between model proteins and CDS-PMo12@PVP NPs occurs spontaneously mainly by hydrophobic forces, whereas the electrostatic interactions make the main forces between proteins and CDS-PMo $\mathrm{P}_{12} @ \mathrm{PVP}_{1}$ NPs. Molecular docking results indicated that the introduction of PVP reduces the number of binding sites and contact surface area. LC-MS/MS further indicated that the PVP reduces the plasma proteins adsorption on the CDS-PMo ${ }_{12} @ \mathrm{PVP}_{1}$ NPs. In addition, apolipoprotein as the main composition of adsorption proteins on CDS-PMo ${ }_{12} @ \mathrm{PVP}_{1} \mathrm{NPs}$ is proposed to have dysoponic activity, enhancing the circulation time. Overall, the surface physicochemical properties of NPs have a significant impact on the adsorption of proteins. We believe such regulation of the surface 
physicochemical of NPs and in-depth understanding of the protein adsorption process can effectively facilitate the design of $\mathrm{PMo}_{12}$-based nanodrug.

\section{EXPERIMENTAL AND METHODS}

\section{Reagents}

Keggin-type phosphomolybdic acid $\mathrm{H}_{3} \mathrm{PMo}_{12} \mathrm{O}_{40} \mathrm{xH}_{2} \mathrm{O}$ ( $\mathrm{PMo}_{12}$ ), sodium dodecyl sulfate (SDS), cesium carbonate $\left(\mathrm{Cs}_{2} \mathrm{CO}_{3}\right)$, Polyvinylpyrrolidone (PVP K30, average Mw: 300 000) were obtained from Alfa Aesar. Cyt-C (30398, 95\%), Hb (H2625, 95\%), BSA (A3311, 95\%) proteins, and ammonium hydrogen carbonate $\left(\mathrm{NH}_{4} \mathrm{HCO}_{3}\right)$ were purchased from Sigma-Aldrich (St. Louis, MO, USA) and used without further purification. Sodium citrate, citric acid, acetonitrile, isopropyl alcohol, acetone, ethyl alcohol, and guanidine hydrochloride were acquired from Sinopharm Chemical Reagent (Shanghai, China). Radio immunoprecipitation assay lysis buffer (RIPA) was purchased form Beyotime technology. Macro spin column TARGA C18 was purchased from The Nest Group, Protein LoBind tubes and ultrafiltration tubes $(10 \mathrm{kDa})$ were purchased from Eppendorf. DL-dithiothreitol (DTT) and iodoacetamide (IAA) were supplied by Acros Organics. Sequencing grade modified trypsin (Promega), formic acid (FA), acetonitrile (ACN), methanol, acetic acid, and Pierce BCA protein assay kit were purchased from Thermo Fisher Scientific. Deionized water ( $\rho=18$ M $\Omega \mathrm{cm}, 25^{\circ} \mathrm{C}$ ) was obtained from a Millipore Milli-Q water purification system. Fabrication and Characterization of the CDS-PMo12@PVP $(x=0 \sim 1)$ NPs

CDS-PMo ${ }_{12} @ \mathrm{PVP}_{\mathrm{x}}(\mathrm{x}=0 \sim 1) \mathrm{NPs}$ were synthesized according to the previously described approach with some modifications.[25] Detailed procedures are given in the experimental 
part of the SI. The morphology of the CDS-PMo ${ }_{12} @ \mathrm{PVP}_{\mathrm{x}}(\mathrm{x}=0 \sim 1)$ NPs was observed with transmission electron microscopy (biology TEM, Tecnai G2 spirit Biotwin operated at 120 kV; Talos F200X G2 operated at $200 \mathrm{kV}$ ). The crystalline structure was recorded by X-ray diffractometer (XRD) (Bruker AXS D8 Focus), using Cu Ka radiation ( $\lambda=1.54056$ A). Fourier transform infrared (FT-IR) spectra were acquired from a Nicolet 50 FT-IR spectrometer (Thermo Fisher Scientific, Waltham, MA), ranging from 400 to $4000 \mathrm{~cm}^{-1}$. The UV-Vis absorption spectra were measured on UV $2600 \mathrm{UV}$-Vis spectrophotometer. The nanoparticles distribution characteristics and zeta-potential were measured using a particle size analyzer (Malvern, Nano ZS, Japan). Fluorescence measurements were performed on a Jobin Yvon Horiba Fluoromax-3 spectrophotometer.

\section{Protein adsorption behavior on the CDS-PMo12@PVP $(x=0 \sim 1)$ NPs}

BSA, $\mathrm{Hb}$, and Cyt-C were chosen as models of acidic, neutral, and basic proteins to evaluate the proteins' adsorption behavior on the CDS-PMo ${ }_{12} @ \mathrm{PVP}_{\mathrm{x}}(\mathrm{x}=0 \sim 1)$ NPs. The experiment procedure is below: $1.0 \mathrm{~mL}$ of protein solution was mixed with $5.0 \mathrm{mg}$ of CDS-PMo ${ }_{12} @ \mathrm{PVP}_{\mathrm{x}}(\mathrm{x}=0 \sim 1) \mathrm{NPs}$ and the mixture was shaken vigorously for $20 \mathrm{~min}$ to facilitate the adsorption of proteins. The $\mathrm{pH}$ of the protein solution was controlled by Britton-Robinson (B-R) buffer (a mixture of $40 \mathrm{mmol} / \mathrm{L}$ phosphoric acid, acetic acid, boric acid, and adjusted by $200 \mathrm{mmol} / \mathrm{L}$ sodium hydroxide) within a range of 3-7. After the adsorption process, the solid and liquid phase was separated by centrifugation at $8000 \mathrm{rpm}$ for 6 min and the residual proteins in the aqueous phase were monitored using a UV-vis spectrophotometer in a $1.0 \mathrm{~cm}$ quartz cell by measuring the characteristic adsorption at 406 $\mathrm{nm}$ for $\mathrm{Hb}, 409 \mathrm{~nm}$ for Cyt-C, and $595 \mathrm{~nm}$ for BSA directly. The protein adsorption efficiency was calculated based on the protein concentration before and after adsorption.

\section{Steady-State Fluorescence Quenching Measurements.}


The fluorescence emission spectra of BSA, $\mathrm{Hb}$, and Cyt-C were measured at a constant concentration $(5 \mu \mathrm{M})$ in the presence of an increasing concentration of PMo12-based NPs (0-15 $\mu \mathrm{M}$ in particles). A certain concentration of PMo12-based NPs was added to the protein solutions and incubated for $10 \mathrm{~min}$, and then the mixture was transferred to a quartz cuvette, and their fluorescence spectra were acquired in the range of 300-600 nm when excited at 290 $\mathrm{nm}$. The area under each fluorescence curve was integrated and used to measure the free BSA concentration using a standard calibration curve. The cuvette path length for fluorescence quenching measurements was $1 \mathrm{~cm}$. The slit widths of excitation and emission were set both at $10 \mathrm{~nm}$, respectively.

\section{Molecular docking}

The molecular docking is done on AutoDock Vina software[49] to predict binding parameters, the contact surface area (CSA), and binding energy of three model proteins (BSA, $\mathrm{Hb}$, and Cyt-C) with target nanoparticles. The crystal structures of three model proteins (BSA: 4F5S,[50] Hb: 1G09,[51] and Cyt-C: 2B4Z[52]) used in molecular docking studies were obtained from the RCSB Protein Data Bank (http://www.rcsb.org). The rigid docking method was utilized to evaluate all possible binding sites on three model proteins. The outer surface of target nanoparticles as the interaction area was considered for molecular docking calculation. So, the $\mathrm{H}_{3} \mathrm{PMo}_{12} \mathrm{O}_{40}$ and PVP molecular structures were built using the Hyperchem 8.0.6 program. The geometry of $\mathrm{PMo}_{12} \mathrm{O}_{40}{ }^{3-}$ polyanion and PVP polymer were optimized to minimal energy employing the theoretical level of B3LYP with LanL2DZ (for Mo atom) and 6-31G (for P, O, N, C, and $\mathrm{H}$ atoms) basis sets and implemented in Gaussian 98 program. The AutoDock Vina instruction was considered for input file preparation. The 
414 PDBQT format of three model proteins, $\mathrm{PMo}_{12} \mathrm{O}_{40}{ }^{3-}$ polyanion,[53] and PVP input files were

415 prepared using the AutoDock Tools 1.5.4 package.[49] Each molecular docking calculation 416 produced 20 poses with the exhaustiveness parameter value equal to 1000 . VMD package[54]

417 was used to analyze molecular docking results.

\section{Protein corona preparation and proteomic analysis}

Plasma samples were diluted 1:5 in B-R buffer (a mixture of $40 \mathrm{mmol} / \mathrm{L}$ phosphoric acid, acetic acid, boric acid, and adjusted by $200 \mathrm{mmol} / \mathrm{L}$ sodium hydroxide). To form the protein corona, $0.5 \mathrm{~g}$ CDS-PMo ${ }_{12} @ \mathrm{PVP}_{\mathrm{x}}(\mathrm{x}=0 \sim 1) \mathrm{NPs}$ was mixed with $500 \mu \mathrm{L}$ diluted plasma samples in a tube. The tube was sealed and incubated at $37^{\circ} \mathrm{C}$ for $1 \mathrm{~h}$ with shaking at $300 \mathrm{rcf}$. After incubation, the mixture was centrifuged to separate the nanoparticle-protein complexes from plasma solution for at least $20 \mathrm{~min}$ at $4^{\circ} \mathrm{C}$ at $15,000 \mathrm{rcf}$. Discard the supernatant and wash the pellet with $\mathrm{ddH}_{2} \mathrm{O}(300 \mu \mathrm{L})$. The protein corona was further washed with $200 \mu \mathrm{L}$ of $\mathrm{ddH}_{2} \mathrm{O}$ three times with centrifugal separation. Elute the proteins from the nanoparticles by adding $100 \mu \mathrm{l}$ of RIPA lysis buffer and incubate for 5 min at $95{ }^{\circ} \mathrm{C}$. Pellet the nanoparticles by centrifugation for $15 \mathrm{~min}$ at $15,000 \mathrm{rcf}$ at room temperature, and then transfer the supernatant containing eluted corona proteins to a fresh tube. Determine the protein concentration of the supernatant by Pierce BCA protein assay. The minimum quantity for LC-MS/MS analysis is $20 \mu \mathrm{g}$ of protein per sample. The extracts from each sample $(50 \mu \mathrm{g}$ protein) were mixed with acetone at a volume ratio of $1: 4$, then precipitated at $-20^{\circ} \mathrm{C}$ for $2 \mathrm{~h}$, and centrifuged at $20000 \mathrm{~g}$ for $10 \mathrm{~min}$. The supernatant was poured and the precipitant was washed twice more with acetone. Subsequently, each protein sample (20 $\mu$ g protein) was 
reduced by DTT $\left(60 \mathrm{~min}, 55^{\circ} \mathrm{C}\right.$ ) and free cysteines alkylated with IAA ( $30 \mathrm{~min}, 25^{\circ} \mathrm{C}$ in the dark). After these procedures, protein samples were loaded into $10 \mathrm{kDa}$ ultrafiltration tubes, washed three times with $50 \mathrm{mM} \mathrm{NH} \mathrm{NCO}_{3}$. Samples were incubated with trypsin overnight at $37^{\circ} \mathrm{C}$. Digested peptides were transferred into a C18 peptide clean-up column, washed by Solvent A ( $0.1 \%$ FA in water) and eluted with elution buffer $(60 \%$ ACN and $40 \%$ FA in water). Clean peptides were finally concentrated and dried in a SpeedVac (Eppendorf). All the blood samples were approved by the Human Ethics Review Committee of Science and Technology, Shanghai Jiao Tong University according to the Chinese regulation.

\section{LC-MS/MS analysis}

Samples were analyzed on Q Exactive HF-X mass spectrometer (Thermo Fisher Scientific) with nano spray flex ion source and Thermo Scientific ${ }^{\mathrm{TM}}$ EASYnLCTM 1200 integrated ultra high-pressure nano HPLC system. The purified and dried peptides (500 ng) were re-dissolved in Solvent A and then automatically injected and loaded onto the trap column $(75 \mu \mathrm{m} \times 2$ cm; particle size, $3 \mu \mathrm{m}$; pore size, $100 \AA$; Thermo Fisher Scientific) at a flow rate of $2 \mu \mathrm{l}$ $\min ^{-1}$ (max pressure $500 \mathrm{bar}$ ). After $5 \mathrm{~min}$, the peptides were eluted from the trap column and separated on the analytical column $(75 \mu \mathrm{m} \times 25 \mathrm{~cm}$; particle size, $2 \mu \mathrm{m}$; pore size, $100 \AA$; Thermo Fisher Scientific) by a gradient ranging from $8 \%$ to $100 \%$ of $\mathrm{ACN}$ mobile phase at $300 \mathrm{~nL} \mathrm{~min}{ }^{-1}$ flow rate for $120 \mathrm{~min}$.

\section{Label-free based protein identification and quantification}

The acquired MS raw data were loaded to Proteome Discoverer@ (version 2.4, Thermo Scientific) software for label-free quantification. The database search was specified by 
trypsin as enzyme for digestion and peptides with up to two missed cleavages were included. The data exported from Proteome Discoverer was analyzed using Excel ${ }^{\odot}$ software. The normalized abundance for proteins and peptides were used for subsequent statistical analysis. Missing value and coefficient of variation (CV) value were mainly used for MS performance quality control. $k$-nearest neighbors algorithm was used for the missing value imputation method. The CV value was used to evaluate the dispersion of the replicates within one group, and proteins with $\mathrm{CV} \leqslant 0.3$ were considered reliable here. In addition, $P$-value was adjusted by Benjamin \& Hochberg (BH, 1995) method. The normalized abundance ratio of CDS-PMo ${ }_{12} @ \mathrm{PVP}_{1} / \mathrm{CDS} \mathrm{PMo}_{12} @ \mathrm{PVP}_{0}$ was used for the calculation the FC. Differentially adsorption proteins were identified according to the following two criterions: $P$-value $<0.01$ and $\mathrm{FC}>2$ and $\mathrm{FC}<0.5$.

\section{Author information}

\section{Corresponding Author}

dingxianting@sjtu.edu.cn hyxie@sjtu.edu.cn

\section{Author Contributions}

The manuscript was written through the contributions of all authors. All authors have approved the final version of the manuscript. $\$$ These authors contributed equally.

\section{Acknowledgment}


This work is supported by the National Science Foundation of China $(22077079,81871448)$, Shanghai Municipal Education Commission Project (ZXWF082101), Shanghai Municipal Science and Technology Project (2017SHZDZX01 and 18430760500).

\section{References}

1. Pope MT. Introduction to Polyoxometalate Chemistry. Polyoxometalate Mol Sci. $2003 ; 3-31$.

2. Yamase T. Anti-tumor, -viral, and -bacterial activities of polyoxometalates for realizing an inorganic drug. J Mater Chem. 2005;15:4773-82.

3. Miras HN, Yan J, Long DL, Cronin L. Engineering polyoxometalates with emergent properties. Chem Soc Rev. 2012;41:7403-30.

4. Fu L, Gao H, Yan M, Li S, Li X, Dai Z, et al. Polyoxometalate-Based Organic-Inorganic Hybrids as Antitumor Drugs. Small. 2015;11:2938-45.

5. Dolbecq A, Dumas E, Mayer CR, Mialane P. Hybrid organic-inorganic polyoxometalate compounds: From structural diversity to applications. Chem Rev. 2010;110:6009-48.

6. Ogata A, Mitsui S, Yanagie H, Kasano H, Hisa T, Yamase T, et al. A novel anti-tumor agent, polyoxomolybdate induces apoptotic cell death in AsPC-1 human pancreatic cancer cells. Biomed Pharmacother. 2005;59:240-4. 
7. Mitsui S, Ogata A, Yanagie H, Kasano H, Hisa T, Yamase T, et al. Antitumor activity of polyoxomolybdate, [NH3Pri]6[Mo7O24] $3 \mathrm{H} 2 \mathrm{O}$, against, human gastric cancer model. Biomed Pharmacother. 2006;60:353-8.

8. Ogata A, Yanagie H, Ishikawa E, Morishita Y, Mitsui S, Yamashita A, et al. Antitumour effect of polyoxomolybdates: Induction of apoptotic cell death and autophagy in in vitro and in vivo models. Br J Cancer. 2008;98:399-409.

\section{Nmr H, Nmr C. Enhanced Antileukemic Activity of the Novel Complex}

2,5-Dihydroxybenzoate Molybdenum(VI) against 2,5-Dihydroxybenzoate, Polyoxometalate of Mo(VI), and Tetraphenylphosphonium in the Human HL-60 and K562 Leukemic Cell Lines. Society. 2007;1316-21.

10. Dong Z, Tan R, Cao J, Yang Y, Kong C, Du J, et al. Discovery of polyoxometalate-based HDAC inhibitors with profound anticancer activity in vitro and in vivo. Eur J Med Chem [Internet]. Elsevier Masson SAS; 2011;46:2477-84. Available from: http://dx.doi.org/10.1016/j.ejmech.2011.03.036

11. Wang L, Yu K, Zhou B Bin, Su ZH, Gao S, Chu LL, et al. The inhibitory effects of a new cobalt-based polyoxometalate on the growth of human cancer cells. J Chem Soc Dalt Trans. 2014;43:6070-8.

12. Zhai F, Wang X, Li D, Zhang H, Li R, Song L. Synthesis and biological evaluation of decavanadate $\mathrm{Na} 4 \mathrm{Co}(\mathrm{H} 2 \mathrm{O}) 6 \mathrm{~V} 10 \mathrm{O} 28 \cdot 18 \mathrm{H} 2 \mathrm{O}$. Biomed Pharmacother. 2009;63:51-5. 
13. Wang L, Zhou B Bin, Yu K, Su ZH, Gao S, Chu LL, et al. Novel antitumor agent, trilacunary keggin-type tungstobismuthate, inhibits proliferation and induces apoptosis in human gastric cancer SGC-7901 cells. Inorg Chem. 2013;52:5119-27.

14. Hadjidemetriou M, Kostarelos K. Nanomedicine: Evolution of the nanoparticle corona. Nat Nanotechnol. Nature Publishing Group; 2017;12:288-90.

15. Cedervall T, Lynch I, Lindman S, Berggård T, Thulin E, Nilsson H, et al. Understanding the nanoparticle-protein corona using methods to quntify exchange rates and affinities of proteins for nanoparticles. Proc Natl Acad Sci U S A. 2007;104:2050-5.

16. Tiambeng TN, Roberts DS, Brown KA, Zhu Y, Chen B, Wu Z, et al. Nanoproteomics enables proteoform-resolved analysis of low-abundance proteins in human serum. Nat Commun. Nature Research; 2020;11.

17. Walkey CD, Chan WCW. Understanding and controlling the interaction of nanomaterials with proteins in a physiological environment. Chem Soc Rev. 2012;41:2780-99.

18. Zou Y, Ito S, Yoshino F, Suzuki Y, Zhao L, Komatsu N. Polyglycerol Grafting Shields Nanoparticles from Protein Corona Formation to Avoid Macrophage Uptake. ACS Nano. 2020;14:7216-26.

19. Deng ZJ, Liang M, Monteiro M, Toth I, Minchin RF. Nanoparticle-induced unfolding of fibrinogen promotes Mac-1 receptor activation and inflammation. Nat Nanotechnol. Nature Publishing Group; 2011;6:39-44. 
20. Moghimi SM, Andersen AJ, Hashemi SH, Lettiero B, Ahmadvand D, Hunter AC, et al. Complement activation cascade triggered by PEG-PL engineered nanomedicines and carbon nanotubes: The challenges ahead. J Control Release [Internet]. Elsevier B.V.; 2010;146:175-81. Available from: http://dx.doi.org/10.1016/j.jconrel.2010.04.003

21. Pelaz B, Del Pino P, Maffre P, Hartmann R, Gallego M, Rivera-Fernández S, et al. Surface Functionalization of Nanoparticles with Polyethylene Glycol: Effects on Protein Adsorption and Cellular Uptake. ACS Nano. 2015;9:6996-7008.

22. Laschewsky A, Rosenhahn A. Molecular Design of Zwitterionic Polymer Interfaces: Searching for the Difference. Langmuir. 2019;35:1056-71.

23. Roser M, Fischer D, Kissel T. Surface-modified biodegradable albumin nano- and microspheres. II: Effect of surface charges on in vitro phagocytosis and biodistribution in rats. Eur J Pharm Biopharm. 1998;46:255-63.

24. Wang RY, Jia DZ, Zhang L, Liu L, Guo ZP, Li BQ, et al. Rapid synthesis of amino acid polyoxometalate nanotubes by one-step solid-state chemical reaction at room temperature. Adv Funct Mater. 2006;16:687-92.

25. Maayan G, Popovitz-Biro R, Neumann R. Micelle directed synthesis of polyoxometalate nanoparticles and their improved catalytic activity for the aerobic oxidation of sulfides. J Am Chem Soc. 2006;128:4968-9. 
26. Guo R, Cheng Y, Ding D, Li X, Zhang L, Jiang X, et al. Synthesis and Antitumoral Activity of Gelatin/Polyoxometalate Hybrid Nanoparticles. Macromol Biosci. 2011;11:839-47.

27. Blandamer MJ, Briggs B, Cullis PM, Irlam KD, Engberts JBFN, Kevelam J. Titration microcalorimetry of adsorption processes in aqueous systems: Interaction of sodium dodecylsulfate and sodium decylsulfate with poly(N-vinylpyrrolidone). J Chem Soc Faraday Trans. 1998;94:259-66.

28. Bertrand N, Grenier P, Mahmoudi M, Lima EM, Appel EA, Dormont F, et al. Mechanistic understanding of in vivo protein corona formation on polymeric nanoparticles and impact on pharmacokinetics. Nat Commun [Internet]. Springer US; 2017;8. Available from: http://dx.doi.org/10.1038/s41467-017-00600-w

29. Tahar A, Benadji S, Mazari T, Dermeche L, Marchal-Roch C, Rabia C. Preparation, Characterization and Reactivity of Keggin Type Phosphomolybdates, H3-2x Ni x PMo12O40 and (NH4)3-2x Ni x PMo12O40, for Adipic Acid Synthesis. Catal Letters. 2015;145:569-75.

30. Daoud-Attieh M, Chaib H, Armutcu C, Uzun L, Elkak A, Denizli A. Immunoglobulin G purification from bovine serum with pseudo-specific supermacroporous cryogels. Sep Purif Technol [Internet]. Elsevier B.V.; 2013;118:816-22. Available from: http://dx.doi.org/10.1016/j.seppur.2013.08.026 
31. Ghalandari B, Asadollahi K, Shakerizadeh A, Komeili A, Riazi G, Kamrava SK, et al. Microtubule network as a potential candidate for targeting by gold nanoparticle-assisted photothermal therapy. J Photochem Photobiol B Biol [Internet]. Elsevier; 2019;192:131-40. Available from: https://doi.org/10.1016/j.jphotobiol.2019.01.012

32. De Paoli Lacerda SH, Park JJ, Meuse C, Pristinski D, Becker ML, Karim A, et al. Interaction of gold nanoparticles with common human blood proteins. ACS Nano. 2010;4:365-79.

33. Evale BG, Hanagodimath SM. Static and dynamic quenching of biologically active coumarin derivative by aniline in benzeneacetonitrile mixtures. J Lumin [Internet]. Elsevier; 2010;130:1330-7. Available from: http://dx.doi.org/10.1016/j.jlumin.2010.03.011

34. Melavanki RM, Kusanur RA, Kadadevaramath JS, Kulakarni M V. Quenching mechanisms of 5BAMC by aniline in different solvents using Stern-Volmer plots. J Lumin [Internet]. Elsevier; 2009;129:1298-303. Available from: http://dx.doi.org/10.1016/j.jlumin.2009.06.011

35. Evale BG, Hanagodimath SM. Fluorescence quenching of newly synthesized biologically active coumarin derivative by aniline in binary solvent mixtures. J Lumin [Internet]. Elsevier; 2009;129:1174-80. Available from: http://dx.doi.org/10.1016/j.jlumin.2009.05.017 
36. Melavanki RM, Kusanur RA, Kulakarni M V., Kadadevarmath JS. Role of solvent polarity on the fluorescence quenching of newly synthesized 7,8-benzo-4-azidomethyl coumarin by aniline in benzene-acetonitrile mixtures. J Lumin. 2008;128:573-7.

37. Tablet C, Hillebrand M. Quenching of the fluorescence of 3-carboxy-5,6-benzocoumarin by aromatic amines. J Photochem Photobiol A Chem. 2007;189:73-9.

38. Liang L, Subirade M. $\beta$-lactoglobulin/folic acid complexes: Formation, characterization, and biological implication. J Phys Chem B. 2010;114:6707-12.

39. Shafaei Z, Abazari O, Divsalar A, Ghalandari B, Poursoleiman A, Saboury AA, et al. Effect of a Synthesized Amyl-Glycine1, 10-Phenanthroline Platinum Nitrate on Structure and Stability of Human Blood Carrier Protein, Albumin: Spectroscopic and Modeling Approaches. J Fluoresc. Journal of Fluorescence; 2017;27:1829-38.

40. Miller JN. Photoluminescence and chemiluminescence methods of drug analysis. J Pharm Biomed Anal [Internet]. 1983;1:525-35. Available from: http://www.sciencedirect.com/science/article/pii/0731708583800661

41. Divsalar A, Saboury AA, Yousefi R, Moosavi-Movahedi AA, Mansoori-Torshizi H. Spectroscopic and cytotoxic studies of the novel designed palladium(II) complexes: $\beta$-Lactoglobulin and K562 as the targets. Int J Biol Macromol. 2007;40:381-6.

42. Osadebe PO, Onugwu LE, Attama AA. Energetics of the interaction between piroxicam and beta-cyclodextrin ( $\beta$-CD) in inclusion complexes. Sci Res Essays. 2008;3:086-93. 
43. Azam Gholamian, Adeleh Divsalar, Maryam Saiedifar, Behafarid Ghalandari, Ali Akbar Saboury BK. Generation of reactive oxygen species via inhibition of liver catalase by oxalli-palladium: A spectroscopic and docking study.

44. Timaseff SN. Thermodynamics of protein interactions. Proteins Biol fluids. Pergamon Press Oxford; 1972;697:511-9.

45. Ke Y, Huang S, Ghalandari B, Li S, Warden AR, Dang J, et al. Hairpin-Spacer crRNA-Enhanced CRISPR/Cas13a System Promotes the Specificity of Single Nucleotide Polymorphism (SNP) Identification. Adv Sci. John Wiley and Sons Inc; 2021;8.

46. Addona TA, Shi X, Keshishian H, Mani DR, Burgess M, Gillette MA, et al. A pipeline that integrates the discovery and verification of plasma protein biomarkers reveals candidate markers for cardiovascular disease. Nat Biotechnol. 2011;29:635-43.

47. Geyer PE, Kulak NA, Pichler G, Holdt LM, Teupser D, Mann M. Plasma Proteome Profiling to Assess Human Health and Disease. Cell Syst. Cell Press; 2016;2:185-95.

48. Blume JE, Manning WC, Troiano G, Hornburg D, Figa M, Hesterberg L, et al. Rapid, deep and precise profiling of the plasma proteome with multi-nanoparticle protein corona. Nat Commun. Nature Research; 2020;11.

49. Allouche A. Software News and Updates Gabedit - A Graphical User Interface for Computational Chemistry Softwares. J Comput Chem. 2012;32:174-82. 
619 50. Bujacz A. Structures of bovine, equine and leporine serum albumin. Acta Crystallogr Sect 620 D Biol Crystallogr. 2012;68:1278-89.

621 51. Mueser TC, Rogers PH, Arnone A. Interface sliding as illustrated by the multiple 622 quaternary structures of liganded hemoglobin. Biochemistry. 2000;39:15353-64.

623 52. Sanchez G. Las instituciones de ciencia y tecnología en los procesos de aprendizaje de la 624 producción agroalimentaria en Argentina. El Sist argentino innovación Inst Empres y redes 625 El desafío la creación y apropiación Conoc. 2013;83-92.

626 53. Paul TJ, Parac-Vogt TN, Quiñonero D, Prabhakar R. Investigating

627 Polyoxometalate-Protein Interactions at Chemically Distinct Binding Sites. J Phys Chem B. $628 \quad 2018 ; 122: 7219-32$.

629 54. Humphrey W, Dalke A, Schulten K. VMD: Visual molecular dynamics. J Mol Graph. $630 \quad 1996 ; 14: 33-8$. 


\section{Supplementary Files}

This is a list of supplementary files associated with this preprint. Click to download.

- GraphicalAbstract.docx

- 20210826JournalofNanotechnologySupportinginformation.docx 